\title{
Prediction of Sediment Deposition in Reservoir Using Analytical Method
}

\author{
Rajendra Patil ${ }^{*}$, Rajeev Shetkar \\ Civil Engineering Department, Government College of Engineering, Aurangabad, India
}

Email address:

rapatildkte@yahoo.co.in (R. Patil)

*Corresponding author

\section{To cite this article:}

Rajendra Patil, Rajeev Shetkar. Prediction of Sediment Deposition in Reservoir Using Analytical Method. American Journal of Civil Engineering. Vol. 4, No. 6, 2016, pp. 290-297. doi: 10.11648/j.ajce.20160406.14

Received: August 23, 2016; Accepted: August 31, 2016; Published: September 18, 2016

\begin{abstract}
Sediment particles, a product of erosion in the catchment are transported along the river with flowing water. The construction of Weir, barrage or a dam causes obstruction to the flow resulting in reduction of velocity. The reduced velocity causes sedimentation resulting in reduction of storage capacity which affects the overall life of the reservoir. The sediment deposition in the reservoir is a continuous and complex process which affects the useful life of a reservoir. The quantification of sediment deposition in a reservoir is necessary for effective reservoir and river basin management. The present study has been carried out to assess sediment deposition in Koyna Reservoir which is located in the Western Maharashtra, India. In India most of the rainfall is caused due to the southwest monsoon during the period from June to September, massive convective thunderstorms dominate the weather. In the present study analytical methods are used for estimation of sediment deposited in the Koyna reservoir. For the prediction annual inflow data is used. The storage capacity of Koyna reservoir is calculated considering the loss of storage due to sediment deposition for a period from 1961 to 2375 . The results obtained indicated a loss of reservoir capacity by the year 2004, as $267.25 \mathrm{Mm}^{3}(9.55 \%)$. The physical measurement indicated that the Koyna reservoir had lost $293.09 \mathrm{Mm}^{3}$ $(10.48 \%)$ of its capacity by the year 2004 . The results obtained by analytical method have $8.82 \%$ error compared with the actual measurements.
\end{abstract}

Keywords: Reservoir, Inflow, Sedimentation, Capacity, Deposition

\section{Introduction}

India experiences very high unpredictability in the amount and the pattern of rainfall in various regions of the country. To cope up with such diverse situation, varieties of small and big projects are developed in India. Very few potential sites are to be considered as good sites for the major projects considering all constraints. The available storage capacity of existing reservoirs is to be utilized and evaluated very carefully as good storage sites being limited. The sediment deposition pattern basically affects the storage capacity of the catchment area. Conventional techniques, such as hydrographic surveys and the inflow-outflow methods being used for quantification of sediment deposition in a reservoir are expensive and time consuming. The effect of soil attrition from the catchment, sediment transport and catching efficiency of the reservoir affects the fertility of land. Considering the above issues, development of simple and cost effective method for quantification of sediment deposition in a reservoir is the need of time.

The reservoirs capacity is getting decaying due to filling up of sediments year after years. With yearly reduction in capacity by approximately $1 \%$, the overall water storage capacity will become nearly half over a period of about 50 years. The reservoirs especially built for irrigation, water supply and power generation will hamper economics in a great extent and has environmental concerns. In this situation, reduction in the rate of sedimentation or cleaning the reservoirs becomes out most important. Many studies on reservoir sedimentation are going on since 1950s but the prediction phenomenon seems complex due to processes involved. The variables involved in sedimentation process need to be collected are not so reliable affecting the useful life [1]. The estimation of sedimentation depends on variable parameters such as sediments and inflow rates of water, which 
seems to be time dependent [2]. Prediction of forthcoming discharges of water and the sediments in river studies are found to be less reliable [3]. The empirical approaches can be used to generate future data if ample records of these parameters are available. Many times it is observed that the rate of sedimentation found in some of the Indian reservoirs is too high than the planned. The reservoirs are found to be losing its capacity annually by $0.2-1.0 \%$ [4] due to constant impingement of the live storage by sediments [5]. Studies on assessment of sedimentation in Bhakra Reservoir across Satluj River by a remote sensing approach indicated average sedimentation rate of $25.23 \mathrm{Mm}^{3} /$ year for a period of 32 years. Whereas by using hydrographic survey data showed 20.84 $\mathrm{Mm}^{3} /$ year for the same period, which indicates that the remote sensing based approach provides results matching very closely with the hydrographic surveys [6]. The rating curves prepared from measurement data of suspended sediment and water discharge has shown $0.17 \%$ per year loss of storage capacity of reservoir in monthly and annual sediment inflow predictions of the reservoir [7] in India. The satellite studies on sedimentation rate by analyzing the images using the software noted $229 \mathrm{~m}^{3} / \mathrm{km}^{2}$ of catchment area per year [8].

The Indian rivers found to carry approximately 0.16 $\mathrm{t} / \mathrm{km}^{2} /$ year sediments along with flow of water, of which approximately $10 \%$ is found to be deposited in reservoirs and $29 \%$ is carried away into the sea [9]. Reservoir sedimentation affects water storage capacity and its availability during scarcity period. The analysis of 43 sedimentations surveys of major, medium and minor reservoirs in India indicates that, the sedimentation rate varies between $0.34-27.85$ ha $\mathrm{m} / 100$ $\mathrm{km}^{2}$ / year for major reservoirs, $0.15-10.65$ for medium reservoirs and $1.0-2.3 \mathrm{ha} \mathrm{m} / 100 \mathrm{~km}^{2} /$ year for minor reservoirs [10].

The sediment coming from catchment results in to loss of capacity of reservoir, there is direct relation between runoff and sediment yield. For a sustainable development through water resources planning and management, timely and accurate estimation of runoff and sediment yield are essential. On arrival of sediment-laden water in to the reservoir, the coarser particles settle first in the upper reaches of the reservoir due to heavy weight, subsequently, the finer sediments also get deposited. Sediment deposition into reservoirs that are built for power generation are adversely affected due to loss of storage, damage to equipment, bank erosion, etc. All the major rivers of Central Asia are turbid watercourses affected by high sedimentation rates. It is of importance to quantify available water resources in reservoirs to ensure assured water supply to the stake holders. Geographic factors such as surface slope, soil texture, land use, climatic factors like rainfall, temperature, runoff etc., influence the soil erosion and sediment yield process. Rainfall, runoff and consequent soil erosion are temporally and spatially distributed processes. A better estimation of runoff and sediment yield is feasible by considering the watershed as small unit and applying the hydrologic model. Even though good results are obtained, it is a laborious and time consuming approach.
Assessment of reservoir sedimentation is part of the basic information needed for the operation and management of any reservoir. The knowledge of sedimentation process will help in ensuring remedial measures to be taken in advance so that the reservoir operation can be planned for optimum utilization. For this, capacity survey of a reservoir is conducted periodically using conventional equipment. The two most common conventional techniques for quantifying sedimentation in a reservoir are direct measurement of sediment deposition by hydrographic surveys, and indirect measurement using the inflow-outflow records of a reservoir. Both these methods are cumbersome, time consuming and expensive. Remote sensing techniques, offering data acquisition over a long time period and for a broad spectral range, are considered superior to the conventional methods for data acquisition. Spatial, spectral and temporal attributes of remote sensing data provide valuable and timely information regarding changes in the water-spread area after sedimentation and sediment distribution patterns in the reservoir [11].

\section{Methods of Runoff and Sediment Yield}

Hydrological models used for runoff and sediment yield estimation may be classified as empirical, conceptual and distributed models. Empirical models are developed by building a relationship between two or more hydrologic parameters with the long observed field data. The conceptual models are based on physics of the problem that consider some of the predominant processes on a watershed [12]. But the distributed models are based on incorporating the spatial and temporal variability of physiographic and climatic factors.

\subsection{Modeling Methods}

Estimates of runoff and sediment yield are essential for the solution of a number of problems of a watershed. The modeling of rainfall-runoff and soil erosion /sediment yield from watersheds has received considerable attention. The models are expected to assist in assessment of water yield, extent of soil and nutrient losses and sediment transport, Land use planning, soil conservation measures and understanding of runoff and erosion processes and their interactions. The hydrologic modeling efforts have moved from traditional empirical lumped models to distributed models. Attempts have been made to adopt computationally intensive and nonlinear but efficient techniques such as Neural Networks for rainfall- runoff and soil erosion modeling. Most of these models have adopted Neural Networks for temporal modeling of run off.

\subsection{Conventional Hydrological Models}

All models (conventional and modern) under real conditions are more or less incorrect $[13,14]$, because of the abstractions and simplifications of the original complex and nonlinear hydrologic processes [15]. It is very difficult to measure all the model parameters precisely, they are always data based. About 28 hydrologic models, were evaluated by 
ASCE Task Committee, for adopting them in absence of data for un-gauged basins [16]. The hydrologic modeling took off from traditional empirical models to conceptual lumped models and to the present day distributed models. The availability of high speed and large memory computing systems have made the computationally intensive and nonlinear techniques such as neural networks most applicable to hydrologic modeling.

\subsection{Runoff Modeling}

In any hydrologic analysis, rainfall-runoff relationship plays the key role. To determine the amount of runoff, besides observations made in the field, computer models and simulations can also be used. These are useful for extrapolating the observed runoff records. Depending on the purpose, data availability, type of runoff result desired, the estimation is done by any of the methods, such as, linear and multiple linear regression models, unit hydrograph method, rational method and hydrological models. Linear and multiple linear regression models relate rainfall and runoff, using a statistical relation fitting a linear regression. Runoff estimation in India has also been carried out traditionally by using Barlow's tables, Strange's tables and Inglis formula. Empirical Models are developed using observed rainfall and runoff data and correlating with other basin parameters which influence the runoff transformation process. Some of them are rational formula, Cook's table, SCS model, Dicken's formula, Ryves formula, Inglis formula, Craig's formula, Time of concentration, etc. Rational Method is based on the catchment area, rainfall intensity and a runoff coefficient that depends on the land use $[17,18]$. Cook's Method is a relationship between rainfall factor of a basin, return period of peak runoff and rainfall [17].

\subsection{Sediment Yield Modeling}

Some of the efforts made to develop methods to estimate soil erosion that total soil loss is related to the degree and length of slope [19]. A soil loss equation was developed based on factors such as soil erodibility, land cover, degree and length of slope and 30-minute maximum rainfall with a frequency of 2 years [20]. Sediment Yield Prediction Equation was developed for soil erosion assessment including terrain factors such as topography, soils, rainfall, and the climatic factors [21]. This equation was modified into a multiple linear regression form. Another regression based sediment yield model was developed using data from 50 catchments in India that includes the physiographic factors such as slope, drainage density, soils, land use and climatic factor i.e. rainfall [6]. Assessment of sediment yield is carried out using the model developed by Garde and Kothyari for varying land [22].

\section{Present Study}

In the present study, analytical method proposed by Garde et al [23] is used to calculate the volume of sediment deposited $\left(\mathrm{V}_{\mathrm{ac}}\right)$ in the Koyna reservoir for the available annual inflow data, available for a period from 1961 to 2013 and also for future. The available annual inflows are used to generate the flows for the subsequent years using Brittan's method by means of Markov-Chain model as given by VenTe Chow [18].

\subsection{Objective of the Study}

In view of the above, the specific objectives of the present study are,

a) To predict the volume of sediment deposition in Koyna reservoir using analytical method.

b) To compute the capacity of reservoir by analytical method.

\subsection{Study Area}

The area selected for the present study model application is the Koyna watershed, situated on the west coast of Maharashtra, India, lies between the latitude of $17^{0} 00^{\prime}-17^{0} 59^{\prime}$ $\mathrm{N}$ and longitude of $73^{0} 02^{\prime}-73^{0} 35^{\prime} \mathrm{E}$. The location of the study area along with nine rain-gauge stations in the Koyna watershed is shown in figure 1 [24]. The Koyna project is a multi- purpose project, initially designed as a hydro- electric project with an installed capacity of 1920 MW. The Koyna watershed has an elongated leaf shape. The total catchment area of the Koyna reservoir is $891.8 \mathrm{sq} . \mathrm{km}$. The catchment is approximately $64 \mathrm{~km}$. in length and 12 to $14 \mathrm{~km}$. in width. The catchment is bounded by hills. The water spread area is 115.36 sq. km. The catchment is broadly classified as $41 \%$ forest area, $49 \%$ cultivated area, $6 \%$ waste land, $4 \%$ others. The total capacity of the reservoir is $2797.5 \mathrm{Mm}^{3}$, out of which live storage is $2677.7 \mathrm{Mm}^{3}$ and dead storage is 119.8 $\mathrm{Mm}^{3}$.

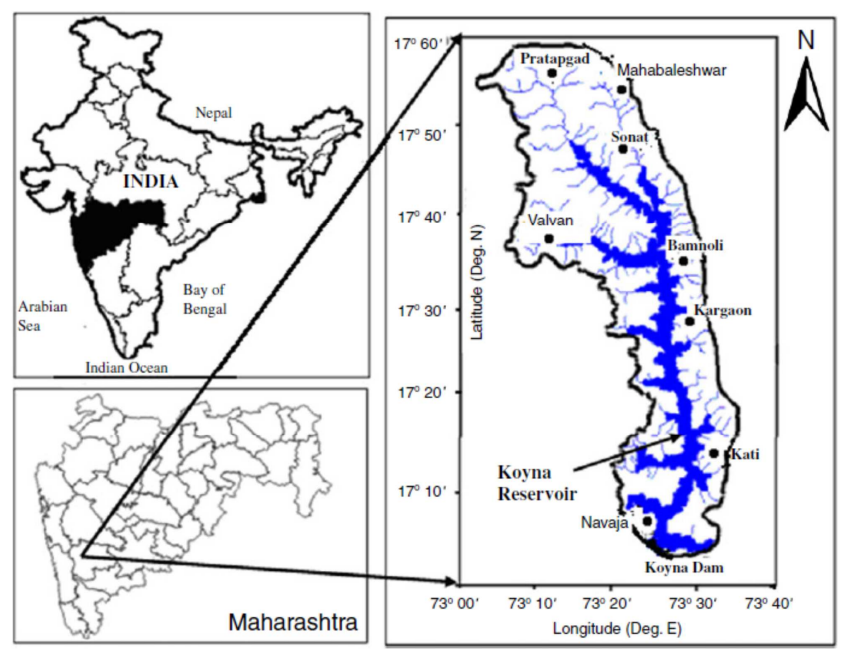

Figure 1. Study area, Koyna watershed.

\section{Methodology}

The Empirical or analytical methods are used for calculating the sediment deposition in the reservoir. One of the methods which is proposed by Garde et al [23] is used in this study to estimate the sediment deposition in the Koyna reservoir. This method is more practical and it is extremely 
useful technique since it represents a procedure relying on the integration of complex erosion, sediment transport and deposition process in reservoirs [22]. This method makes use of the data which is generally available for any reservoir. The data used is the annual inflows to the reservoir, initial capacity of reservoir, average initial bed slope, width of reservoir at full reservoir level. Using these details the inflow in to the Koyna reservoir and sediment deposition due to this inflow is calculated.

\subsection{Inflow Generation}

The available annual inflow (1961-2013) is used to generate the flows for subsequent years using Brittan's method by means of Markov-chain Model [18].

$$
Q_{(\mathrm{t}+1)}=R Q_{t}+(1-R) \bar{Q}+\sigma\left(1-R^{2}\right) Z
$$

$Q_{(\mathrm{t}+1)}=$ Generated water inflow in $(t+1)^{\text {th }}$ year

$Q_{t}=$ Annual water inflow in $t^{\text {th }}$ year

$\bar{Q}=$ Mean annual inflow of historic data

$R=$ First order serial correlation coefficient. of historic inflow data

$\sigma=$ Standard deviation of historic inflow data.

$Z=$ Random normal deviate having zero mean and unit standard deviation.

First order serial correlation co-efficient $(R)$, standard deviation $(\sigma)$ and random normal deviate are calculated for inflow generation.

a) First order serial co-efficient $R$ is given by

$$
R=\frac{\sum_{i=1}^{N-1} X_{i}^{*} X_{i+1}-\frac{1}{N-1}\left(\sum_{i=1}^{N-1} X_{i}\right)\left(\sum_{i=1}^{N-1} X_{i+1}\right)}{\left(\sum_{i=1}^{N-1} X_{i}^{2}-\frac{1}{N-1}\left(\sum_{i=1}^{N-1} X_{i}\right)^{2}\right)^{1 / 2} *\left(\sum_{i=1}^{N-1} X_{i+1}{ }^{2}-\frac{1}{N-1}\left(\sum_{i=1}^{N-1} X_{i+1}\right)^{2}\right)^{1 / 2}}
$$

b) Standard deviation of historic inflow data $(\sigma)$

$$
\sigma=\left[\left\{\frac{\sum X_{i}^{2}}{N-1}-\left(\frac{\sum X_{i}}{N-1}\right)^{2}\right\}^{1 / 2} *\left\{\frac{\sum X_{i+1}^{2}}{N-1}-\left(\frac{\sum X_{i+1}}{N-1}\right)^{2}\right\}^{1 / 2}\right]^{1 / 2}
$$

where,

$X_{i}=$ Historic annual inflow in $i^{\text {th }}$ year

$X_{i+1}=$ Historic annual inflow in $(i+1)^{\text {th }}$ year

$N=$ Number of years

c) Random normal deviate $(\mathrm{Z})$

It is found out by the Box Muller method using rectangular distributed random numbers using the equations.

$$
\begin{aligned}
& Z_{1}=\left[-2 \operatorname{In}\left(1-U_{1}\right)\right]^{1 / 2} \operatorname{Cos}\left(2 \pi U_{2}\right) \\
& Z_{2}=\left[-2 \operatorname{In}\left(1-U_{1}\right)\right]^{1 / 2} \operatorname{Sin}\left(2 \pi U_{2}\right)
\end{aligned}
$$

where, $U_{1}$ and $U_{2}$ are the uniformly distributed random numbers in the range $(0,1)$.

\subsection{Volume of Sediment Deposited}

The cumulative volume of sediment deposited is calculated from the cumulative volume of water inflow into the reservoir which is used for the generation of future rate of sedimentation [22].

$$
\begin{aligned}
& V_{s}=V_{a c} * B / 10^{6} \\
& V_{a c}=1.16^{*}\left(S_{0}\right)^{0.84} *\left(V_{w}\right)^{0.94} \\
& V_{w}=Q_{c} / B
\end{aligned}
$$

Where,

$V_{s}=$ Volume of sediment in $\mathrm{Mm}^{3}$

$V_{a c}=$ Cumulative volume of sediment in $\mathrm{M}^{3} / \mathrm{m}$ width of reservoir in $t$ years
$V_{w}=$ Cumulative volume of water inflow in $\mathrm{M}^{3} / \mathrm{m}$ width in $\mathrm{t}$ years

$S_{0}=$ Average initial longitudinal bed slope along the deepest course of reservoir

$Q_{c}=$ Cumulative annual volume of water inflow in $\mathrm{Mm}^{3}$

$B=$ Average width of reservoir at full reservoir level in $\mathrm{m}$

\section{Results and Discussion}

The inflow prediction is generated based on the historical flow data and Generated inflows are used to estimate the future sediment deposition in Koyna reservoir.

\subsection{Inflow Generation}

The available annual inflows are used to generate the flows for subsequent years using Brittan's method based on the Markov-Chain Model [18], given by equation (1).

$\bar{Q}=$ Mean annual inflow of historic data $=3983.02 \mathrm{Mm}^{3}$

$N=$ Number of historical data available $=53$

$R=$ First order serial correlation co-efficient of historic inflow data $=0.1520$

$\sigma=$ Standard deviation of historic inflow data $=982.8414$

The above values are taken as input to generate the inflow for Koyna reservoir and inflow was generated from 2014 to 2375 ( 362 years) and the generated inflow is as given table 1 and represented in Figure 2.

\subsection{Sediment Deposition}

The volume of sediment deposit in the reservoir was calculated by using the equation (2).

$$
\begin{aligned}
& V_{s}=V_{a c} * B / 10^{6} \\
& V_{a c}=1.16^{*}\left(S_{0}\right)^{0.84} *\left(V_{w}\right)^{0.94} \\
& V_{w}=Q_{c} / B
\end{aligned}
$$


$B=$ Average width of reservoir at F.R.L $=2097 \mathrm{~m}$.

$S_{0}=$ Average initial longitudinal bed slope along the deepest course of reservoir $=1$ in 705.94.

The future sediment deposition in reservoir is shown in table 2 and represented in Figure 3.

\subsection{Discussion}

Using Equation (1), the predicted inflow into the reservoir is generated. Flow is generated for the period from 2014 to 2375 ; i.e. for 362 years, which is as shown in Table 2. The predicted volume of sediment deposit in the Koyna reservoir is also calculated using the equation (2) and capacity of the reservoir is also calculated, is given in the Figure 3. Volume of sediment deposition was calculated up to the year 2375 , as this is the year, when reservoir will lose $75 \%$ of its capacity.
It is to be noted that any reservoir that loses its intended capacity to $75 \%$ of original capacity it becomes non-feasible [25]. The percentage loss in reservoir capacity is shown in Figure 4.

\section{Conclusions}

The capacity of Koyna reservoir is calculated based on the sediment deposition in the reservoir from 1961 to 2375 by analytical method. According to this method, in the year 2004, the loss in capacity of reservoir was 267.25 Mcum $(9.55 \%)$. But Koyna reservoir has lost 293.09 Mcum $(10.48 \%)$ of its capacity in the year 2004 [26]. From this result, one can say that analytical method suggested [23] gives better results.

Table 1. Generated inflow.

\begin{tabular}{|c|c|c|c|c|c|}
\hline Year & Generated inflow $\mathrm{Mm}^{3}$ & Year & Generated inflow $\mathrm{Mm}^{3}$ & Year & Generated inflow $\mathrm{Mm}^{3}$ \\
\hline 2015 & 3918.09 & 2140 & 5436.63 & 2265 & 6894.04 \\
\hline 2020 & 3816.53 & 2145 & 3094.97 & 2270 & 3115.86 \\
\hline 2025 & 3148.29 & 2150 & 3119.54 & 2275 & 4049.08 \\
\hline 2030 & 4724.06 & 2155 & 3600.80 & 2280 & 2289.14 \\
\hline 2035 & 4101.79 & 2160 & 5040.12 & 2285 & 3284.95 \\
\hline 2040 & 2035.25 & 2165 & 3345.07 & 2290 & 3716.92 \\
\hline 2045 & 5726.20 & 2170 & 2729.44 & 2295 & 3372.66 \\
\hline 2055 & 5880.27 & 2180 & 3435.43 & 2305 & 3435.55 \\
\hline 2060 & 2900.40 & 2185 & 3889.20 & 2310 & 3294.99 \\
\hline 2065 & 4660.56 & 2190 & 3667.64 & 2315 & 4123.17 \\
\hline 2070 & 3278.42 & 2195 & 3339.98 & 2320 & 1273.14 \\
\hline 2075 & 3878.84 & 2200 & 4435.69 & 2325 & 4250.99 \\
\hline 2080 & 3751.97 & 2205 & 1991.52 & 2330 & 2314.41 \\
\hline 2085 & 3088.23 & 2210 & 1631.91 & 2335 & 5502.83 \\
\hline 2100 & 2163.67 & 2225 & 3356.96 & 2350 & 3606.26 \\
\hline 2105 & 5069.02 & 2230 & 3538.77 & 2355 & 3059.00 \\
\hline 2110 & 4759.12 & 2235 & 4106.59 & 2360 & 4863.67 \\
\hline 2115 & 3419.55 & 2240 & 3288.95 & 2365 & 3380.79 \\
\hline 2120 & 4193.18 & 2245 & 3033.59 & 2370 & 1681.17 \\
\hline 2125 & 2716.15 & 2250 & 4862.34 & 2375 & 4040.18 \\
\hline 2130 & 4271.71 & 2255 & 4376.23 & & \\
\hline 2135 & 3361.24 & 2260 & 3534.77 & & \\
\hline
\end{tabular}

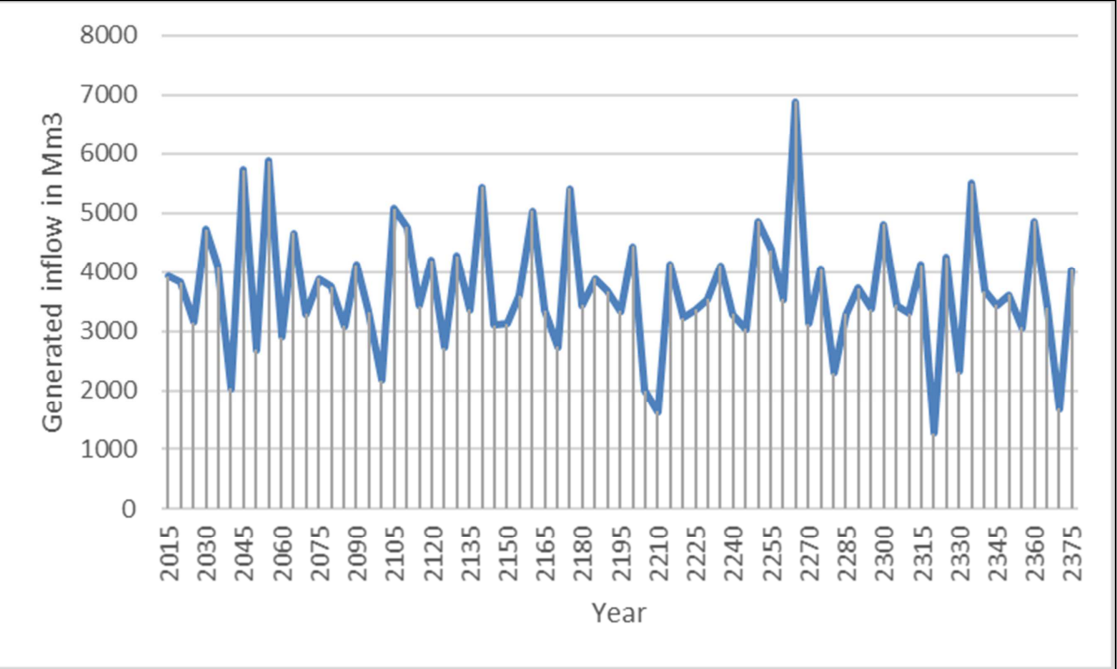

Figure 2. Yearly generated inflow. 


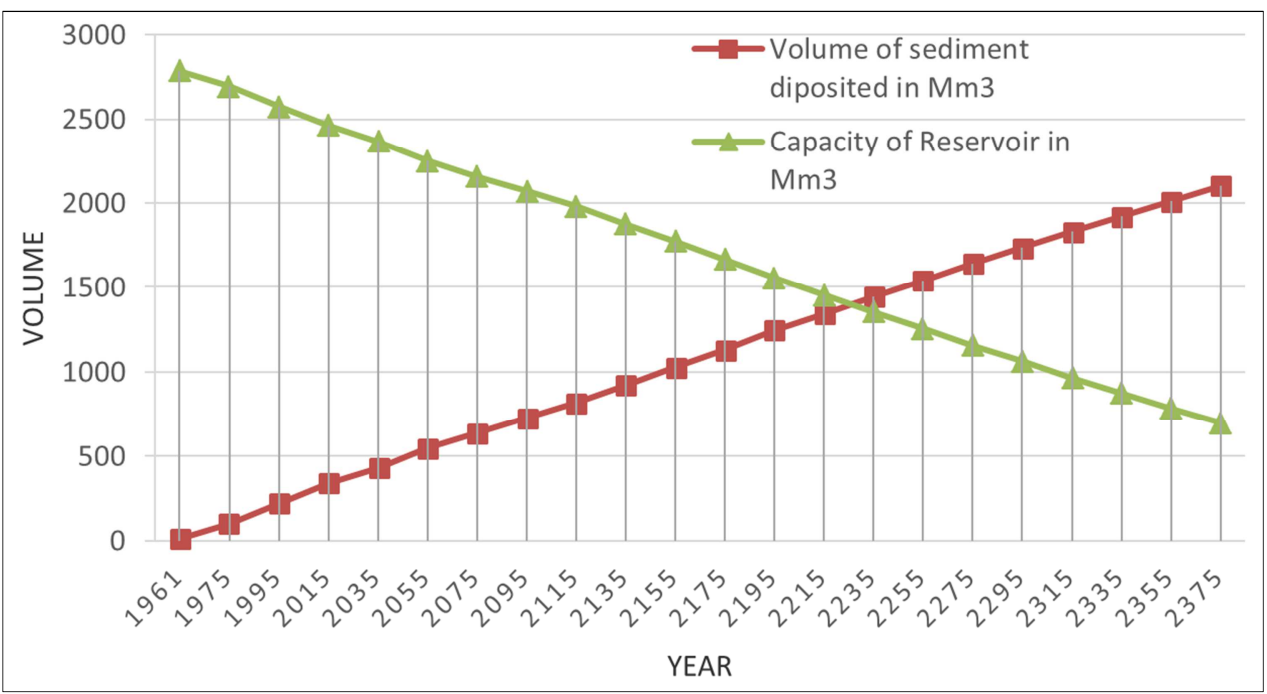

Figure 3. Sediment deposition and reservoir capacity.

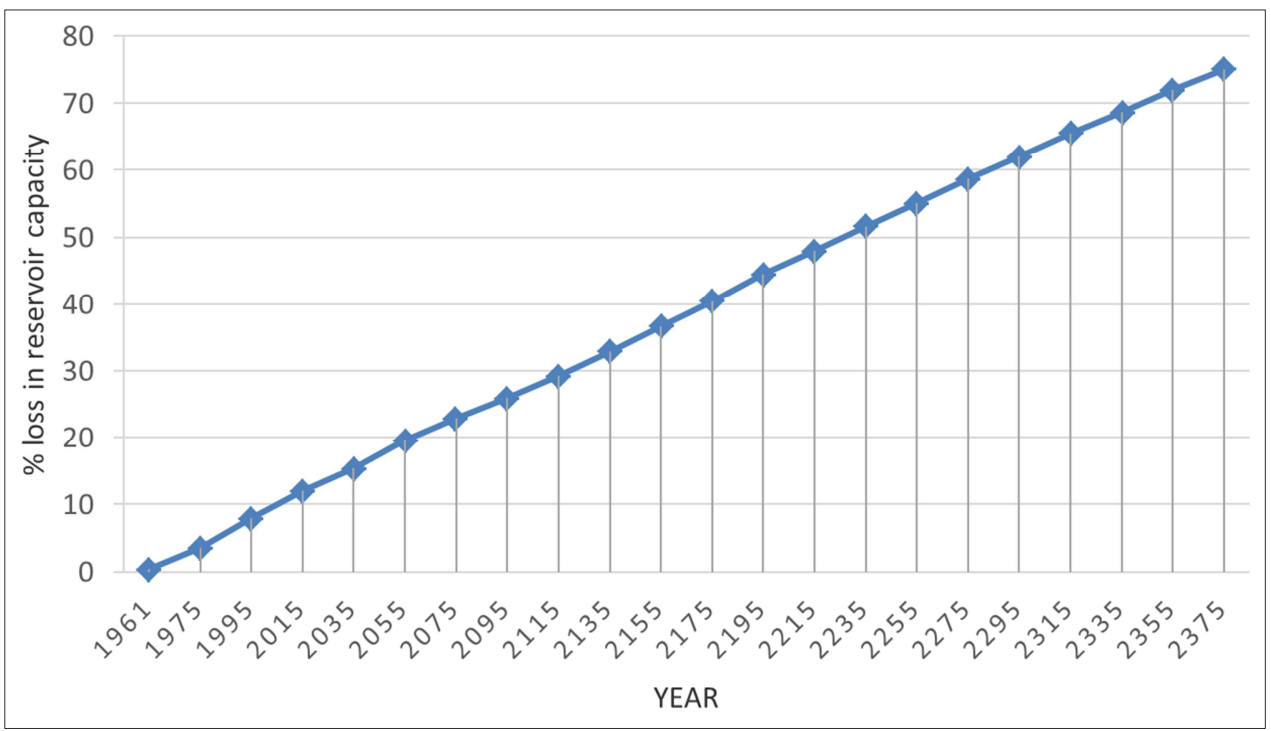

Figure 4. Percentage capacity loss.

Table 2. Volume of sediment deposition.

\begin{tabular}{|c|c|c|c|c|c|c|c|}
\hline Year & $\begin{array}{l}\text { Volume of sediment } \\
\text { accum. } \mathrm{Mm}^{3}\end{array}$ & $\begin{array}{l}\text { Capacity of } \\
\text { Reservoir } \mathrm{Mm}^{3}\end{array}$ & $\begin{array}{l}\text { \% Loss in Reservoir } \\
\text { Capacity }\end{array}$ & Year & $\begin{array}{l}\text { Volume of sediment } \\
\text { accum. } \mathrm{Mm}^{3}\end{array}$ & $\begin{array}{l}\text { Capacity of } \\
\text { Reservoir } \mathrm{Mm}^{3}\end{array}$ & $\begin{array}{l}\text { \% Loss in Reservoir } \\
\text { Capacity }\end{array}$ \\
\hline 1961 & 10.36 & 2787.14 & 0.37 & 2001 & 252.62 & 2544.88 & 9.03 \\
\hline 1962 & 16.96 & 2780.54 & 0.61 & 2002 & 257.04 & 2540.46 & 9.19 \\
\hline 1963 & 24.30 & 2773.20 & 0.87 & 2003 & 261.25 & 2536.25 & 9.34 \\
\hline 1964 & 32.06 & 2765.44 & 1.15 & 2004 & 267.25 & 2530.25 & 9.55 \\
\hline 1965 & 39.09 & 2758.41 & 1.40 & 2005 & 276.75 & 2520.75 & 9.89 \\
\hline 1966 & 44.54 & 2752.96 & 1.59 & 2006 & 286.50 & 2511.00 & 10.24 \\
\hline 1968 & 57.67 & 2739.83 & 2.06 & 2008 & 299.58 & 2497.92 & 10.71 \\
\hline 1969 & 64.81 & 2732.69 & 2.32 & 2009 & 303.98 & 2493.52 & 10.87 \\
\hline 1970 & 71.77 & 2725.73 & 2.57 & 2010 & 308.73 & 2488.77 & 11.04 \\
\hline 1971 & 78.11 & 2719.39 & 2.79 & 2011 & 315.81 & 2481.69 & 11.29 \\
\hline 1972 & 82.17 & 2715.33 & 2.94 & 2012 & 321.10 & 2476.40 & 11.48 \\
\hline 1973 & 89.00 & 2708.50 & 3.18 & 2013 & 327.96 & 2469.54 & 11.72 \\
\hline 1974 & 94.08 & 2703.42 & 3.36 & 2014 & 331.38 & 2466.12 & 11.85 \\
\hline 1977 & 114.84 & 2682.66 & 4.11 & 2055 & 548.35 & 2249.15 & 19.60 \\
\hline 1978 & 122.36 & 2675.14 & 4.37 & 2075 & 640.64 & 2156.86 & 22.90 \\
\hline 1979 & 128.09 & 2669.41 & 4.58 & 2095 & 727.26 & 2070.24 & 26.00 \\
\hline
\end{tabular}




\begin{tabular}{llllllll}
\hline Year & $\begin{array}{l}\text { Volume of sediment } \\
\text { accum. } \mathbf{M m}^{\mathbf{3}}\end{array}$ & $\begin{array}{l}\text { Capacity of } \\
\text { Reservoir } \mathbf{M m}^{\mathbf{3}}\end{array}$ & $\begin{array}{l}\text { \% Loss in Reservoir } \\
\text { Capacity }\end{array}$ & Year & $\begin{array}{l}\text { Volume of sediment } \\
\text { accum. } \mathbf{M m}^{\mathbf{3}}\end{array}$ & $\begin{array}{l}\text { Capacity of } \\
\text { Reservoir } \mathbf{M m}^{\mathbf{3}}\end{array}$ & $\begin{array}{l}\text { \% Loss in Reservoir } \\
\text { Capacity }^{2}\end{array}$ \\
\hline 1980 & 135.20 & 2662.30 & 4.83 & 2115 & 817.27 & 1980.23 & 29.21 \\
1981 & 141.24 & 2656.26 & 5.05 & 2135 & 920.95 & 1876.55 & 32.92 \\
1982 & 146.72 & 2650.78 & 5.24 & 2155 & 1026.31 & 1771.19 & 36.69 \\
1983 & 152.89 & 2644.61 & 5.47 & 2175 & 1132.13 & 1665.37 & 40.47 \\
1984 & 158.53 & 2638.97 & 5.67 & 2195 & 1243.31 & 1554.19 & 44.44 \\
1985 & 163.48 & 2634.02 & 5.84 & 2215 & 1343.00 & 1454.50 & 48.01 \\
1986 & 168.31 & 2629.19 & 6.02 & 2235 & 1444.72 & 1352.78 & 51.64 \\
1987 & 172.24 & 2625.26 & 6.16 & 2255 & 1539.51 & 1257.99 & 55.03 \\
1988 & 178.07 & 2619.43 & 6.37 & 2275 & 1641.97 & 1155.53 & 58.69 \\
1989 & 182.33 & 2615.17 & 6.52 & 2295 & 1734.56 & 1062.94 & 62.00 \\
1990 & 190.22 & 2607.28 & 6.80 & 2315 & 1833.29 & 964.21 & 65.53 \\
1991 & 196.78 & 2600.72 & 7.03 & 2335 & 1923.00 & 874.50 & 68.74 \\
1992 & 201.95 & 2595.55 & 7.22 & 2355 & 2014.71 & 782.79 & 72.02 \\
1993 & 208.44 & 2589.06 & 7.45 & 2375 & 2100.72 & 696.78 & 75.09 \\
1994 & 217.99 & 2579.51 & 7.79 & & & & \\
1995 & 222.05 & 2575.45 & 7.94 & & & & \\
1996 & 226.83 & 2570.67 & 8.11 & & & & \\
1997 & 234.01 & 2563.49 & 8.36 & & & & \\
1998 & 238.99 & 2558.51 & 8.54 & & & & \\
1999 & 244.90 & 2552.60 & 8.75 & & & \\
2000 & 248.79 & 2548.71 & 8.89 & & & & \\
\hline
\end{tabular}

\section{References}

[1] Arnold, J. G., Williams, J. R., Nicks, A. D. and Sammons, N. B. "SWRRBWQ, A Basin Scale Simulation Model for Soil and Water Resources Management", Texas A\&M Press, College Station, TX. 1990.

[2] ASCE Task Committee on Quantifying Land - Use Change effects of the Watershed Management and Surface - Water Committees of Irrigation and Drainage Division. "Evaluation of Hydrologic Models Used to Quality Major Land - Use Change Effects", Journal of Irrigation and drainage Engineering, ASCE, Vol. 111, No. 2, pp. 1-17, 1985.

[3] Central Water Commission (CWC). "Compendium on silting of reservoirs in India, Water Planning and Projects Wing, Environment Management Organisation, Watershed and Reservoir Sedimentation Directorate, CWC, New Delhi, India, 2001.

[4] Chao, P. C. and Ahmed, S. "Mathematical model for reservoir sedimentation planning" International Water Power and Dam Construction, Vol. 37, No. 1, pp. 45-50, 1985.

[5] Flaxman, E. M. "Predicting sediment yield in western US", Journal of hydraulic division, ASCE, Vol. 100 (HY5), pp. 693-695, 1974.

[6] Garde, R. J. (1995). Reservoir sedimentation. State of art report no. INCOH/SAR-6/95, INCOH, National Institute of Hydrology, Roorkee.

[7] Garde, R. J. and Kothyari, U. C. (1986) "Erosion in Indian Catchments", International Symposium on River Sedimentation, Jackson, (Mississippi), USA.

[8] Garde, R. J. and U. C. Kothari (1987) "Sediment Yield Estimation" CBIP publication, 97-120.

[9] Garde, R. J., P. K. Swamee and M. E. Dalvi. "Estimation of progressive deposition in reservoirs", Proceedings of $47^{\text {th }}$ research session, CBIP Publication, Vol. I, pp. 1-50, 1978.

[10] Goel M. K., Sharad K. Jain and P. K. Agarwal (2002),
"Assessment of sediment deposition rate in Bargi Reservoir using digital image processing", Hydrological Sciences Journal, 47 (S): S81-S92.

[11] Haan, C. T., Johnson, H. P. and Brakenseik, D. L. "Hydrologic Modelling of Small Watersheds", An ASAE Monograph, No. 5, ASAE, St. Joseph, MI, USA, 1982.

[12] Jain Sanjay K., Pratap Singh and S. M. Seth (2002), "Assessment of sedimentation in Bhakra Reservoir in the western Himalayan region using remotely sensed data", Hydrological Sciences Journal, 47 (2): 203-212

[13] Kamel Khanchoul Mohamed Benslama, Boualem Remini (2010), " Regressions on Monthly Stream Discharge to Predict Sediment Inflow to a Reservoir in Algeria", Journal of Geography and Geology, 2 (1), 36-47

[14] Lane, L. J., Shirley, E. D. and Singh, V. P. "Modelling Erosion on Hillslopes", in "Modelling Geomorphological Systems", edited by Anderson, M. G., John Wiley \& Sons Ltd., pp. 287-308, 1988.

[15] Lorup, J. K. and Styczen, M. "Soil Erosion Modeling", in Distributed Hydrological Modelling', edited by Abbott, M. B. and Refsgaard, J. C., Kluwier Academic Publishers, pp. 93-120, 1996.

[16] Magar, R. B., and Jothiprakash, V. (2011), "Intermittent reservoir daily-inflow prediction using lumped and distributed data multi-linear regression models" Journal of Earth System Science, Vol. 120. No. 6, pp 1067-1084.

[17] McKeogh, E. J. "Sedimentation control in Indian reservoirs", International Water Power \& Dam Construction, Vol. 33, No. 10, pp. 41-43, 1981.

[18] Muftuoglu, R. F. "New models for N o n -linear Catchment Analysis", Journal of Hydrology, Vol. 73, pp. 335-357, 1984.

[19] Musgrave, G. W. "The Quantitative Evaluation of Factors in Water Erosion - A First Approximation", Journal of Soil and Water Conservation, Vol. 2, No. 3, pp. 133-138, 1947.

[20] Narayana, D. \& Ram Babu (1983) "Estimation of soil erosion from India”, Irrig. Drain. Div. ASCE 109 (4), 419-434. 
[21] Santosh Kumar Garg. "Irrigation Engineering and Hydraulic Structures" Khanna Publishers, 2009.

[22] Shangale, A. K. (1991). Reservoir sedimentation status in India. Jalvigyan Sameeksha, INCOH, NIH Roorkee, VI (1\&2).

[23] Swamee, P. K. "Reservoir capacity depletion on account of sedimentation", International Journal of Sediment Research, Vol. 16, No. 3, pp. 408-415, 2001.
[24] Technical Report on Sedimentation of Koyna Reservoir (1980, 1986 and 2004), MERI.

[25] Ven Te Chow, "Statistical and Probability analysis of Hydrologic data", Hand book of Hydrology, 1964.

[26] Zingg, R. W. "Degree and Length of Land Slope as it Affects Soil Loss in Runoff", Agricultural Engineering, Vol. 21, pp. 59-64, 1940. 